\title{
HUBUNGAN ANTARA PERHATIAN ORANG TUA DENGAN KEMANDIRIAN BELAJAR PADA SISWA KELAS IV SDN PINANG RANTI 01
}

\author{
Sania Nurcahya ${ }^{1}$, Septi Fitri Meilana ${ }^{2}$ \\ ${ }^{12}$ PGSD FKIP Universitas Muhammadiyah Prof. DR. HAMKA \\ ${ }^{1}$ sanianurcahya@gmail.com, ${ }^{2}$ septi.fitri.meilana@uhamka.ac.id
}

\begin{abstract}
In the family, there are parents who have the obligation to give attention and affection to their children, and have a great responsibility for the development of children's behavior. Parents's attention to children doesn't only drop off and pick up children's school, but also guides them in learning, provides good learning facilities and pays attention to children's learning development. This can make children more independent and responsible for their obligations. The purpose of this research was to establish the relationship between parent's attention and learning independence in $4^{\text {th }}$ grade students of SDN Pinang Ranti 01 Pagi. Population and sample of this research were all fourth graders at SDN Pinang Ranti 01 Pagi, totaling 86 students. The data collection technique used a questionare, while the product moment correlation is used for data analysis technique in research, and obtained $r$ count value 0,486 and $r$ table with $N=86$ is obtained by 0,210. Thus, the value of $r$ count has a value greater than $r$ table is obtained 0,486 $>0,210$. So, the conclusion of this research thas $H_{a}$ accepted, which means that there is a relationship between parent's attention and independence learning in $4{ }^{\text {th }}$ grade students of SDN Pinang Ranti 01 Pagi.
\end{abstract}

Keywords: parent's attention, independence learning

\section{ABSTRAK}

Dalam lingkungan keluarga, terdapat orang tua yang berkewajiban memberi kasih sayang dan perhatian terhadap anak, serta memiliki tanggung jawab yang besar dalam perkembangan perilaku anak. Perhatian orang tua kepada anak tidak hanya mengantar dan menjemput sekolah anak begitu saja, tetapi juga membimbingnya dalam belajar, memberikan sarana belajar yang baik dan memperhatikan perkembangan belajar anak. Hal ini dapat menjadikan anak lebih mandiri dan bertanggung jawab terhadap kewajibannya. Tujuan penelitian ini yaitu mengetahui adanya hubungan antara perhatian orang tua dengan kemandirian belajar pada siswa kelas IV SDN Pinang Ranti 01 Pagi. Populasi dan sampel penelitian ini yaitu seluruh siswa kelas IV SDN Pinang Ranti 01 Pagi dengan jumlah 86 siswa. Teknik pengumpulan data yaitu menggunakan kuesioner, sedangkan korelasi product moment digunakan untuk teknik analisis data dalam penelitian dan diperoleh nilai rhitung sebesar 0,486 dan $r_{\text {tabel }}$ dengan $N=86$ sebesar 0,210 . Sehingga, nilai rhitung memperoleh nilai lebih besar dari $r_{\text {tabel }}$ sebesar 0,486 0,210. Dengan demikian disimpulkan bahwa $\mathrm{H}_{\mathrm{a}}$ dapat diterima, yang artinya terdapat hubungan antara 
perhatian orang tua dengan kemandirian belajar pada siswa kelas IV SDN Pinang Ranti 01 Pagi.

Kata Kunci: perhatian orang tua, kemandirian belajar

\section{A. Pendahuluan}

Saat ini menyebarnya virus COVID-19 yang terjadi di berbagai negara, terutama Indonesia membuat pemerintah mengambil keputusan untuk menutup pelaksanaan pembelajaran secara tatap muka dan dialihkan dengan pembelajaran online. Dalam pembelajaran online, pengawasan kepada siswa tidak dapat dilakukan oleh guru secara penuh seperti sebelumnya, sehingga tugas mengontrol dan mengawasi siswa menjadi tugas orang tua sepenuhnya. Namun, orang tua pun banyak yang sibuk dengan pekerjaan lainnya sehingga tidak dapat mengawasi anaknya saat proses pembelajaran secara online berlangsung.

Perubahan tingkah laku siswa sangat diutamakan dalam proses belajar. Dengan diterapkannya belajar dari rumah, secara tidak langsung mewajibkan siswa untuk menanamkan kemampuan belajar secara mandiri. Kemandirian sangatlah penting dalam kehidupan manusia. Kemandirian dapat menjadikan anak lebih bertanggung jawab dan tumbuhnya rasa percaya diri yang lebih besar. Anak yang memiliki kemandirian lebih mampu memecahkan masalahnya sendiri tanpa menuntut bantuan orang lain. Kemandirian yang terjadi dalam proses pembelajaran adalah kemandirian belajar.

Kemandirian belajar adalah kemampuan memiliki sikap mandiri dalam bertindak seperti aktif dalam belajar, memiliki sikap disiplin dalam melaksanakan proses pembelajaran dan tidak menggantungkan dirinya kepada orang lain (Kemalasari \& Ismanto, 2018). Kemandirian belajar dapat disebabkan oleh dua faktor, pertama ialah faktor internal yang melingkupi daya tarik siswa, kondisi fisik siswa, motivasi siswa dan kedua ialah faktor eksternal yang melingkupi lingkungan sekolah, lingkungan masyarakat serta lingkungan keluarga.

Lingkungan pada keluarga merupakan tempat paling utama pada pendidikan anak. Dalam lingkungan keluarga, terdapat orang tua yang 
mempunyai kewajiban memberikan kasih sayang terhadap anaknya, serta memegang kendali yang besar terhadap perkembangan perilaku anak. Orang tua dapat memberikan rasa kasih sayang terhadap anak dalam berbagai macam bentuk, salah satunya ialah adanya perhatian orang tua (Aufar Zulfahmi \& Masturi, 2020).

$$
\text { Perhatian orang tua }
$$

merupakan pemfokusan aktivitas aktivitas orang tua terhadap anak baik secara fisik ataupun non fisik. Perhatian orang tua sangat diperlukan untuk membimbing dan mendidik anak - anaknya agar dimasa depannya dapat hidup mandiri dan tidak bersandar kepada orang lain (Chen dikutip dari Endriani, 2016, p. 108). Perhatian orang tua kepada anak tidak hanya mengantar dan menjemput sekolah anak begitu saja, tetapi juga membimbingnya dalam belajar, memberikan sarana belajar yang baik dan memperhatikan perkembangan belajar anak. Hal ini dapat menjadikan anak lebih mandiri dan bertanggung jawab terhadap kewajibannya. Perhatian dan kepedulian orang tua merupakan salah satu kunci dalam meningkatkan kemandirian pada anak (Hikmah et al., 2021, p. 30).
Siswa yang

memiliki kemandirian belajar tinggi cenderung akan mempersiapkan materi sebelum dimulainya pembelajaran dan akan mengulang kembali pembahasan yang telah disampaikan setelah proses pembelajaran berakhir (Mulyadi \& Syahid, 2020, 199). Dengan adanya kemandirian belajar yang baik, diharapkan siswa mampu melaksanakan dan menyiapkan kegiatan proses pembelajarannya sendiri tanpa adanya tuntutan orang sekitar dan sadar akan tanggung jawab dalam menyelesaikan tugas tugasnya secara mandiri.

Namun, kenyataan di lapangan memperlihatkan bahwa kemandirian belajar yang seharusnya membuat siswa memiliki tanggung jawab terhadap dirinya sendiri masih jauh dari harapan. Berdasarkan observasi yang dilakukan pada saat magang $2 \mathrm{di}$ SDN Pinang Ranti 01 Pagi, terdapat beberapa permasalahan yang terjadi di dalam kelas, diantaranya yaitu masih banyaknya siswa yang belum siap menghadapi proses pembelajaran, seperti adanya beberapa siswa yang bergantung kepada temannya saat proses pembelajaran sedang dilaksanakan. Hal ini dapat dilihat ketika siswa diberi 
tugas oleh guru, namun siswa - siswa tersebut memilih bertanya hasil tugas dengan temannya. Permasalahan lain juga terlihat saat pembelajaran yang dilakukan secara daring yaitu masih terdapat beberapa siswa yang tidak mempelajari materi sebelum ada perintah dari guru dan tugas yang dikumpulkan pun tidak tepat waktu. Hal ini menunjukkan rendahnya persiapan belajar dan tanggung jawab siswa terhadap dirinya sendiri. Namun juga terdapat siswa yang sangat aktif dalam pelaksanaan pembelajaran dan mengerjakan tugas - tugasnya dengan mandiri.

Setelah melakukan wawancara terhadap orang tua siswa kelas IV di SDN Pinang Ranti 01 Pagi Jakarta Timur, ternyata masih terdapat beberapa orang tua yang masih kurang mengawasi kegiatan belajar anakna dikarenakan orang tua yang sibuk dengan pekerjaannya sehingga memiliki waktu senggang yang sedikit terhadap anaknya, dan kurang memperhatikan permasalahan belajar yang dihadapi oleh anak. Hal lain juga disebabkan oleh pendidikan orang tua yang mayoritas ialah sekolah menengah, sehingga orang tua kurang memahami perkembangan materi pembelajaran anak dan kurang membimbing anak dalam kegiatan belajarnya. Hal tersebut menjadikan anak merasa kurangnya perhatian orang tua yang diberikan, sehingga menyebabkan anak tidak perduli terhadap tugas - tugas yang diberikan guru dan tidak mempersiapkan kebutuhan belajar dengan sendirinya.

Dengan adanya permasalahan di atas menarik peneliti untuk melakukan penelitian korelasional mengenai "Hubungan antara Perhatian Orang Tua dengan Kemandirian Belajar pada Siswa Kelas IV SDN Pinang Ranti 01 Pagi Jakarta Timur"

Rumusan masalah yang ditarik oleh peneliti berdasarkan latar belakang di atas adalah "Apakah terdapat hubungan yang positif signifikan antara perhatian orang tua dengan kemandirian belajar pada siswa kelas IV SDN Pinang Ranti 01 Pagi?"

\section{B. Metode Penelitian}

Tujuan penelitian korelasional ini yaitu untuk melihat adanya hubungan antara perhatian orang tua (variabel $X)$ dengan kemandirian belajar (variabel Y). Populasi penelitian yang digunakan yaitu seluruh siswa kelas IV SDN Pinang Ranti 01 Pagi yang berjumlah 86 siswa. Riset ini 
dilakukan pada tanggal 25 - 27 Mei 2021 di SDN Pinang Ranti 01 Pagi Tahun Ajaran 2020/2021.

Peneliti menggunakan instrumen angket untuk memperoleh data pada peneitian ini. Angket ialah butir soal yang diajukan kepada responden untuk dijawab. Angket tertutup merupakan jenis angket yang digunakan oleh peneliti, sehingga peneliti telah memiliki pilihan jawaban dan responden hanya perlu memilih jawaban yang telah disediakan. Dalam skala pengukuran pada variabel kemandirian belajar ini peneliti memakai skala likert. Menurut Sugiyono "Skala yang dapat digunakan untuk mengukur perilaku, pendapat serta tanggapan seseorang atau sekelompok orang tentang situasi sosial" (Tresnaningsih et al., 2019).

Indikator yang digunakan dalam mengukur variabel $\mathrm{X}$ (perhatian orang tua) antara lain; 1) Mengatur waktu belajar anak; 2) Membantu anak dalam memecahkan masalah; 3) Mengawasi anak dalam belajar; dan 4) Menyediakan sarana kebutuhan belajar anak. Sedangkan, indikator yang digunakan dalam mengukur variabel $Y$ (kemandirian belajar) yaitu: 1) Berperilaku berdasarkan inisiatif sendiri, 2) Mengetahui tujuan belajar, 3) Menelaah kebutuhan belajar, 4) Memiliki kepercayaan diri, 5) Disiplin diri, 6) Memiliki rasa tanggung jawab.

Skala yang digunakan dalam menilai angket pernyataan positif, yaitu "selalu" = 4, "sering" = 3 , "jarang" $=2$, "tidak pernah" =1. Sedangkan untuk nilai yang digunakan dalam pernyataan negatif, yaitu "selalu" $=1$, "sering" = 2, "jarang" = 3 dan "tidak pernah" $=4$.

Analisis deskriptif dan inferensial menjadi teknik analisis data yang digunakan oleh peneliti dalam melaksanakan riset ini. Langkah langkah yang akan digunakan untuk mendeskripsikan serta mengkaji data setiap variabel penelitian ini yaitu sebagai berikut:

1) Menghitung mean, median, modus, standar deviasi, nilai maksimum dan nilai minimum

2) Menentukan tabel kategori

3) Menurut Syaifudin Azwar dalam (Aultama, 2020, p. 4) menyatakan bila menentukan kategori dapat menggunakan batasan sebagai berikut:

Tabel 1 Pedoman Tingkat Kategori

\begin{tabular}{cc}
\hline Interval & Kategori \\
\hline $\mathrm{X}<($ Mean $-1 \mathrm{SD})$ & Rendah
\end{tabular}


$($ Mean - 1SD) $\leq \mathrm{X}<\quad$ Sedang $($ Mean + 1SD)

$($ Mean $+1 S D) \leq X$

Tinggi

Keterangan:

M: rata - rata / mean

SD: Standar Deviasi

4) Hasil yang diperoleh kemudian dikategorikan berdasarkan tabel di atas.

Validitas isi merupakan uji validitas yang digunakan dalam riset ini. Hal ini dilakukan untuk mengetahui apakah pernyataan - pernyataan dalam angket tersebut layak digunakan sebagai instrumen kemandirian belajar. Validitas isi adalah validitas yang dinilai oleh ahli dibidangnya atau melalui expert judgement (penilaian ahli) terhadap kesesuaian dan relevansi isi tes dengan analisis yang logis (Hendryadi, 2017).

Setelah instrumen dilakukan uji validasi dengan proses review oleh expert judgement, lalu instrumen diujicobakan kepada siswa diluar responden penelitian. Dalam uji coba instrumen, responden yang dipakai yaitu sebanyak $(n)=40$ dengan taraf signifikansi $5 \%$.

Setelah itu, uji reliabilitas menggunakan teknik alpha cronbach dilakukan untuk butir soal yang telah valid. Reliabilitas merupakan perhitungan yang digunakan untuk memperkirakan sejauh mana suatu penilaian tersebut dipercaya, sehingga instrumen dapat dikatakan reliabel jika dapat menjelaskan informasi yang bisa dipercaya (Arikunto dalam Yusup, 2018). Menurut Nunnally "Suatu instrumen dikatakan reliabel apabila nilai Cronbach Alpha > 0,70" (Nuroniyah, 2018). Teknik korelasi product moment dipakai sebagai uji analisis data dalam penelitian ini.

\section{C.Hasil Penelitian dan Pembahasan}

Berdasarkan perhitungan uji validitas menggunakan bantuan program SPSS for windows versi 25 diperoleh 21 butir soal valid pada angket perhatian orang tua dan 28 butir soal valid pada angket kemandirian belajar. Selanjutnya, butir soal yang valid tersebut diuji reliabilitas menggunakan teknik Alpha Cronbach, sehingga diperoleh nilai reliabilitas perhatian orang tua yaitu 0,754 dan kemandirian belajar dengan nilai 0,872. Hal ini menunjukkan bahwa nilai kedua instrumen tersebut dapat dikatakan reliabel, sehingga 
kedua instrumen ini layak digunakan dalam penelitian.

Setelah data diperoleh, dilakukan perhitungan mean, modus, median serta standar deviasi yang kemudian diklasifikasikan berdasarkan tabel kategori. Hasil tersebut menentukan bahwa tingkat perhatian orang tua berada pada kategori sedang dengan rata - rata sebesar $73,58 \%$ pada interval $69 \leq X$ $<78$ (kategori sedang). Orang tua yang menjawab perhatian orang tua rendah sebanyak 8 orang tua dengan presentase sebesar 9,30\%, sedangkan orang tua yang menjawab perhatian orang tua sedang sebanyak 63 orang tua dengan presentase sebesar $73,26 \%$ dan orang tua yang menjawab perhatian orang tua tinggi sebanyak 15 orang tua dengan presentase sebesar $17,44 \%$.

Sedangkan tingkat kemandirian belajar siswa memperoleh rata - rata 95,22 yang berada pada interval $88 \leq$ $X<103$ (kategori sedang). Siswa yang menjawab kemandirian belajar rendah sebanyak 10 siswa dengan presentase sebesar $11,63 \%$, siswa yang menjawab kemandirian belajar sedang sebanyak 56 siswa dengan presentase sebesar $65,12 \%$ dan siswa yang menjawab kemandirian belajar tinggi sebanyak 20 siswa dengan presentase sebesar $23,26 \%$.

Selanjutnya, dilakukan uji normalitas untuk memperlihatkan data berdistribusi normal atau tidak pada taraf signifikan 5\%. Data dapat dinyatakan berdistribusi normal apabila nilai signifikansi $>0,05$. Uji normalitas yang digunakan pada riset ini adalah One Sample Kolmogrov Smirnov yang dibantu oleh program SPSS for windows versi 25. Hasil perhitungan diperoleh nilai 0,200 untuk perhatian orang tua dan nilai 0,176 untuk kemandirian belajar. Artinya, kedua nilai tersebut memiliki nilai yang lebih besar dari 0,05, sehingga dapat dikatakan data kedua variabel memiliki distribusi yang normal.

Selanjutnya, dilakukan uji linearitas menggunakan program SPSS from windows versi 25. Dari hasi tersebut diketahui bahwa Sig. Deviation from Linearity yang diperoleh yaitu $0,112>0,05$, selain itu diperoleh nilai $F_{\text {hitung }} 1,537<F_{\text {tabel }} 1,79$ yang menunjukkan bahwa variabel antara perhatian orang tua dengan kemandirian belajar siswa memiliki hubungan yang linier.

Uji hipotesis dilakukan untuk menunjukkan apakah hipotesis yang 
diajukan dalam penelitian ini dapat diterima atau tidak. Pada riset ini, korelasi product moment pearson digunakan sebagai uji hipotesis dengan rumus sebagai berikut:

$$
r_{x y}=\frac{N \sum X Y-\left(\sum X\right)\left(\sum Y\right)}{\sqrt{\left\{N \sum X^{2}-\left(\sum X\right)^{2}\right\}\left\{N \sum Y^{2}-\left(\sum Y\right)^{2}\right\}}}
$$

Keterangan:

$r_{x y} \quad$ : Koefisien korelasi antara $x$ dan y

$\mathrm{N}:$ : Jumlah responden

$\sum x \quad$ : Jumlah nilai perbutir soal

$\sum y \quad$ : nilai total

$\sum x y$ : Jumlah kali nilai $x$ dan $y$

$\mathrm{X}^{2} \quad$ : Kuadrat dari $\mathrm{x}$ (nilai rata - rata dari $\mathrm{x}$ )

$\mathrm{Y}^{2} \quad$ : Kuadrat dari y (nilai rata - rata dari y)

Hasil analisis data diperoleh rhitung sebesar 0,486 dan rtabel pada $\mathrm{N}=$ 86 sebesar 0,210. Hal ini memperlihatkan bahwa rhitung $_{\text {hat }}=0,486$ $>r_{\text {tabel }}=0,210$, artinya bahwa $\mathrm{Ho}_{\mathrm{o}}$ ditolak dan $\mathrm{H}_{\mathrm{a}}$ diterima yang berbunyi adanya hubungan antara perhatian orang tua dengan kemandirian belajar pada siswa kelas IV SDN Pinang Ranti 01 Pagi. Karena nilai $r_{\text {hitung }}$ menunjukkan nilai yang positif, maka hubungan yang terjadi juga positif dan signifikan dengan nilai signifikansi 0,000 .

Sugiyono mengatakan bila nilai koefisien korelasi berada pada rentang $0,40 \quad-0,59$ artinya menunjukkan hubungan yang sedang (Yunus \& Machmury, 2019, p. 19).. Jadi, dapat diperoleh kesimpulan bahwa adanya hubungan yang positif dan signifikan antara perhatian orang tua dengan kemandirian belajar dan berada pada tingkat kategori sedang.

Untuk menentukan besarnya kontribusi variabel $X$ (perhatian orang tua) terhadap variabel $Y$ (kemandirian belajar) maka dapat dihitung menggunakan koefisien determinasi dengan rumus:

$\begin{aligned} \mathrm{KD} & =r^{2} \times 100 \% \\ \mathrm{KD} & =0,486^{2} \times 100 \% \\ \mathrm{KD} & =23,7 \%\end{aligned}$

Adanya hubungan ini sejalan dengan pendapat Chen (Endriani, 2016) yang menyatakan bahwa Perhatian orang tua sangat diperlukan untuk membimbing dan mendidik anak - anaknya supaya dapat hidup mandiri dan tidak bersandar kepada orang lain. Selain itu, Hikmah et al., (2021, p. 30) juga mengatakan bahwa kunci keberhasilan dalam melatih kemandirian anak yaitu dengan adanya rasa peduli dan perhatian dari orang tua.

Besarnya kontribusi perhatian orang tua terhadap kemandirian belajar siswa pada penelitian ini yaitu sebesar 23,7\%. Kontribusi perhatian 
orang tua tersebut meliputi mengatur waktu belajar anak, membantu anak dalam memecahkan masalah, mengawasi anak dalam belajar dan menyediakan sarana belajar anak. Sedangkan sisanya sebesar $76,3 \%$ dapat dipengaruhi oleh aspek - aspek lain seperti minat belajar, motivasi belajar, adanya keturunan, keadaan sosio ekonomi, pola asuh orang tua dan lingkungan masyarakat.

Hasil pengujian membuktikan bahwa adanya kemandirian belajar yang baik pada siswa didasari oleh perhatian orang tua yang diberikan kepada anak. Sehingga dapat disimpulkan bahwa apabila bertambah baik perhatian orang tua yang diberikan, maka kemandirian belajar yang dimiliki oleh siswa pun juga bertambah baik. Hal ini dapat diketahui berdasarkan uji hipotesis yang menerangkan bahwa $\mathrm{H}_{0}$ ditolak dan $\mathrm{H}_{\mathrm{a}}$ diterima, yang menunjukkan bahwa adanya hubungan yang positif signifikan antara perhatian orang tua dengan kemandirian belajar pada siswa kelas IV SDN Pinang Ranti 01 Pagi Jakarta Timur.

\section{Kesimpulan}

Sesuai dengan hasil penelitian dan pembahasan di atas, maka disimpulkan bahwa terdapat hubungan yang positif signifikan antara perhatian orang tua dengan kemandirian belajar pada siswa kelas IV SDN Pinang Ranti 01 Pagi dengan nilai rhitung $0,486>r_{\text {tabel }}=0,210$. Apabila bertambah baik perhatian orang tua yang diberikan, kemandirian belajar yang dimiliki siswa pun juga bertambah baik.

Dengan keterbatasan ilmu yang dimiliki peneliti, maka peneliti mengusulkan saran seperti berikut:

1. Orang tua diharapkan dapat mendampingi anak saat belajar, menyediakan sarana - sarana belajar serta menanyakan kesulitan - kesulitan belajar yang dialami oleh anak.

2. Siswa diharapkan selalu mandiri, bersemangat dan yakin dalam mengikuti kegiatan pembelajaran.

3. Para pendidik diharapkan dapat selalu bekerjasama dengan orang tua untuk menumbuhkan kemandirian belajar siswa.

4. Peneliti selanjutnya dapat memperdalam aspek - aspek lainnya yang menjadi pengaruh kemandirian belajar diluar aspek perhatian orang tua, sehingga didapati besarnya sumbangan 
aspek tersebut terhadap kemandirian belajar.

\section{DAFTAR PUSTAKA}

Aufar Zulfahmi, E., \& Masturi, M. (2020). Pengaruh Perhatian Orang Tua Terhadap Prestasi Belajar Siswa Kelas V Sd Negeri 1 Kaliwungu Kudus. Pendas: Jurnal Ilmiah Pendidikan Dasar, $\checkmark($ Vol 5 Nomor 2 Desember 2020), 176-186. https://doi.org/10.23969/jp.v5i2.3 058

Aultama, K. E. (2020). Pengaruh perhatian orang tua terhadap hasil belajar peserta didik mata pelajaran ips kelas vii. Jurnal Pendidikan Dan Pembelajaran Khatulistiwa, 9(6), 1-8.

Endriani, A. (2016). Hubungan Perhatian Orang Tua Dengan Motivasi Belajar Pada Siswa Kelas VIII SMPN 6 Praya Timur Lombok Tengah Tahun Pelajaran 2015/2016. Jurnal Realita, 1(2), 104-116.

Hendryadi. (2017). Validitas Isi: Tahap Awal Pengembangan Kuesioner. Jurnal Riset Manajemen Dan Bisnis (JRMB) Fakultas Ekonomi UNIAT, 2(2), 169-178.

Hikmah, D., Syaprudin, D., \& Jannah, M. (2021). Hubungan Perhatian Orangtua terhadap Kemandirian Anak Usia Dini di RA. Jannatu 'Adn Purwakarta Tahun Pelajaran 2019-2020. 2(1), 20-33.

Kemalasari, L. D., \& Ismanto, B. (2018). Pengaruh Motivasi dan Kedisiplinan terhadap Kemandirian Belajar Pelajaran Ekonomi dikalangan Siswa Sekolah Menengah Atas. Pendidikan, 2, 160-166.

Mulyadi, M., \& Syahid, A. (2020). Faktor Pembentuk dari Kemandirian Belajar Siswa. Al-
Liqo: Jurnal Pendidikan Islam, 5(02), 197-214. https://doi.org/10.46963/alliqo.v5i 02.246

Nuroniyah, S. (2018). Pengembangan instrumen pengukuran sikap tanggung jawab siswa madrasah aliyah. Wiyata Dharma: Jurnal Penelitian Dan Evaluasi Pendidikan, 6(2), 134. https://doi.org/10.30738/wd.v6i2. 3392

Tresnaningsih, F., Santi, D. P. D., \& Suminarsih, E. (2019). Kemandirian Belajar Siswa Kelas lii Sdn Karang Jalak I Dalam Pembelajaran Tematik. Pedagogi: Jurnal Penelitian Pendidikan, 6(2), 51-59. https://doi.org/10.25134/pedagog i.v6i2.2407

Yunus, M., \& Machmury, A. (2019). ANALISIS KORELASI ANTARA KEBIASAAN MEMBACA DAN KEMAMPUAN MEMBACA PEMAHAMAN PADA SISWA KELAS IX SMP KEMALA BAYANGKARI MAKASSAR. Jurnal Pendidikan PEPATUDZU, 15(1), 14-20.

Yusup, F. (2018). Uji Validitas dan Reliabilitas Instrumen Penelitian Kuantitatif. Jurnal Tarbiyah: Jurnal IImiah Kependidikan, 7(1), 17-23.

https://doi.org/10.18592/tarbiyah. v7i1.2100 